\title{
Non-seasonal reproduction in inseminating species of Mimagoniates (Characidae, Characiformes) from southern Brazil
}

\author{
Vinicius Renner Lampert ${ }^{1,2}$ \& Marco Aurélio Azevedo ${ }^{1,3}$ \\ 1 Fundação Zoobotânica do Rio Grande do Sul (FZB/RS), Museu de Ciências Naturais (MCN). Porto Alegre, RS, Brasil. \\ ${ }^{2}$ ORCID: 0000-0002-5700-4913. E-mail: vinilampert@gmail.com \\ 3 ORCID: 0000-0002-2795-423X. E-mail: marco.azevedo.ictio@gmail.com
}

\begin{abstract}
Some aspects of reproduction in two species of Mimagoniates, M. microlepis (Steindachner 1877) and M. rheocharis Menezes \& Weitzman 1990 are herein described. Samples were taken monthly from January 1998 to February 1999 in two streams in the locality of Maquiné, Rio Grande do Sul, Brazil. Results from the analysis of hundreds of specimens of M. microlepis and M. rheocharis in two investigated sites indicated mature specimens and peaks of the gonadosomatic index (GSI) along the year. There was a negative and significant correlation between M. microlepis male's GSI and water temperature. Females of the latter species and both sexes of $M$. rheocharis, in turn, showed no correlation with any of the tested parameters (relative stomach weight, day length, rainfall). Absolute and relative fecundity are lower than in externally fertilized species of Characidae. Maximum 0ocyte length was $1.14 \mathrm{~mm}$ for M. microlepis and $1.02 \mathrm{~mm}$ for M. rheocharis and both species were characterized as total spawners based on the type of oocyte development estimated through oocyte size analysis. Features like non-seasonal reproductive period, low fecundity, and insemination may indicate adaptive advantages, which may enhance the chance of survival even with low energetic investment and improved fertilization.
\end{abstract}

Key-Words. Inseminating fish; Small size characins; Reproductive period; Fecundity; Spawning type.

\section{INTRODUCTION}

Mimagoniates species are small fish $(\sim 65 \mathrm{~mm}$ - Braga et al., 2008; 28-60 mm - Menezes \& Weitzman, 2009) which belongs to the subfamily Glandulocaudinae within Characidae, Characiformes. Most members of Glandulocaudinae inhabit water bodies bordered by remnants of the Atlantic rainforest (Weitzman et al., 1996), one of the most threatened biomes in the planet and among the eight priority areas for world's diversity conservation (Myers et al., 2000). Some of the ten species of the subfamily are apparently adapted to narrowly restricted habitats, and limited in distribution by ecology. Some species may be threatened with extinction, and one may already be extinct due to relatively recent habitat alterations, primarily deforestation, by man (Menezes \& Weitzman, 2009). Their geographic distribution ranges from parts of the eastern and southern Brazil, Paraguay, and northeastern Uruguay (Castro et al., 2003; Menezes \& Weitzman, 2009). All species of Mimagoniates are active and colorful, exhibiting shades of blue and brown.

Some interesting traits in these species are the presence of an organ on the base of the caudal fin of adult males which is formed by modified scales and fin rays associated with glandular cells which produce pheromones (Atkins \& Fink, 1979; Weitzman \& Fink, 1985). They also present a complex courtship behavior (Nelson, 1964) and insemination, unusual reproductive traits in characids which lead to transference of sperm into female's oviducts. Burns \& Weitzman (2005) reported about 65 species as inseminating within the Characidae, which corresponds to about 5\% of all species of this family ( 1,350 according to Reis et al., 2003). The mechanism by which this transfer is made remains unknown. It is supposed that fecundation occurs when spermatozoids and oocytes reach the water, once there are no records of embryos or even zygotes in the ovaries of these species (Burns et al., 1995; Castro et al., 2003). The presence of insemination, both in the Glandulocaudini as in other groups of the Characidae, may have led some inseminating species to evolve different reproductive strategies compared to externally fertilized species (Azevedo, 2010).

The great diversity of reproductive strategies found in different fish groups is one of the main aspects of the plasticity found in fish. The understanding of a species reproductive pattern and its influence on population dynamics is an important tool to stock conservation (Vazzoler \& Menezes, 1992). Traits such as reproductive period, fecundity, and spawning type may show 
considerable variation among fish species or even different populations of the same species (Mazzoni \& Iglesias-Rios, 2002).

This work aims to describe some aspects of reproduction in two species of Mimagoniates: M. microlepis (Steindachner, 1877) and M. rheocharis Menezes \& Weitzman, 1990, which inhabit water bodies from Maquiné river basin in the state of Rio Grande do Sul, Brazil. Specifically, it aims to establish if reproduction occurs seasonally, the highest peak of reproductive activity, and which factors, biotic or abiotic, might influence reproduction. Also, it aims to estimate fecundity and oocyte development type. Finally, a discussion on the species reproductive traits and its relation to insemination is provided.

\section{MATERIAL AND METHODS}

\section{Study sites}

Site $1\left(29^{\circ} 38^{\prime} 06^{\prime \prime} \mathrm{S}, 50^{\circ} 14^{\prime} 18^{\prime \prime} \mathrm{W}\right)$ is a stream flowing to Maquiné river close to the main road of the municipality of Maquiné, state of Rio Grande do Sul, Brazil. The stream is relatively narrow with width ranging from 0.5 to 3 meters. The bottom is composed of mud and gravel with depths ranging from 0.15 to 0.60 meters. There are rapids in the narrow places with pools in wider areas of the stream which have turbid waters due to the mud. Site $2\left(29^{\circ} 38^{\prime} 05^{\prime \prime} \mathrm{S}, 50^{\circ} 14^{\prime} 16^{\prime \prime} \mathrm{W}\right)$, is a small stream close to site 1 . It consists of a very narrow and shallow stream which crosses a small dirt road and flows into a deep ditch. The current is fast close to the water entrance in the ditch, slowing down as it gets far from it. The width and depth are about 0.60 and 0.30 meters, respectively, with a sandy-muddy bottom and a lot of organic matter in suspension. During the period of study, the amount of domestic sewer thrown into the water body increased, which makes the water very dark and caused the decrease in the number of fish collected.

\section{Field and laboratory work}

Monthly samples were made between January 1998 and February 1999 with seine net (5 mm mesh) and dip net ( $2.5 \mathrm{~mm}$ mesh) in two sampling sites. Water temperature was measured in the field. Rainfall data were provided by the $8^{\text {th }}$ District of Meteorology of Porto Alegre and day length was obtained with a GPS. Fish were anesthetized with eugenol and then fixed in $10 \%$ formalin. Individual measurements of standard length ( $\mathrm{SL}-\mathrm{mm}$ ), total weight $(\mathrm{Wt}-\mathrm{g})$, gonads weight $(\mathrm{Wg}-\mathrm{g})$ and stomach weight (Ws $-\mathrm{g}$ ) were recorded. Voucher specimens were cataloged in the fish collection of the Museu de Ciências Naturais of Fundação Zoobotânica (MCN 18625, 18626, 19972, 19973, 19974). The gonadosomatic index (GSI) and relative stomach weight (RSW) were calculated according to the following formulas (Santos, 1978): $\mathrm{GSI}=\mathrm{Wg} \times 100 / \mathrm{Wt}$ and $\mathrm{RSW}=\mathrm{Ws} \times 100 / \mathrm{Wt}$, where $\mathrm{Wg}=$ gonads weight, $\mathrm{Wt}=$ total weight, and $\mathrm{Ws}=$ stomach weight. The gonadal maturation stages were established through a macroscopic analysis of the gonads, according to the following authors: Vazzoler, 1996; Azevedo et al., 2000; Lampert et al., 2004. The reproductive period was established through the analysis of the monthly variation of GSI mean values as well as analyzing the relative frequencies of gonadal maturation stages along the sampling period. The absolute fecundity was estimated by counting all yolky oocytes from mature ovaries and the relative fecundity by the number of yolky oocytes per milligram of female's total body weight (Adebisi, 1987). The values of total fecundity were regressed against standard length, total weight and gonads weight to verify how these traits are related. The type of oocyte development was established by measuring the diameter of all oocytes from mature ovaries (Vazzoler, 1996). Size classes were established, and its frequencies were plotted into a graphic. The nonparametric Spearman rank correlation was applied to the monthly mean values of GSI and the monthly mean values of RSW, rainfall, day length and water temperature to verify possible relationships between reproduction and biotic and abiotic factors.

\section{RESULTS}

A total of 602 specimens of M. microlepis and 147 $M$. rheocharis from site 1 and $82 M$. rheocharis from site 2 were analyzed. No samples were made in February 1998. Results from abiotic data and reproductive traits of each species in their respective site are described below.

Site 1 - The 227 males of $M$. microlepis ranged from 17.31 to $42.95 \mathrm{~mm} \mathrm{SL}$, and the 375 females ranged from 15.93 to $41.91 \mathrm{~mm} \mathrm{SL}$. They were collected close to the margins in broad pool areas with slow flow and relatively

Table 1. Monthly variation in mean values of GSI, RSW for males and females of Mimagoniates microlepis from site 1 in Maquiné, RS, Brazil, and rainfall, day length, and water temperature data (January 1998 to February 1999). GSI = gonadosomatic index; $\mathrm{RSW}=$ relative stomach weight.

\begin{tabular}{cccccccc}
\hline Month & GSI $\sigma^{*}$ & GSI 9 & RSW O $^{7}$ & RSW 9 & $\begin{array}{c}\text { Rainfall } \\
(\mathbf{m m})\end{array}$ & $\begin{array}{c}\text { Day } \\
\text { length } \\
\text { (hours) }\end{array}$ & $\begin{array}{c}\text { Temperature } \\
\left({ }^{\circ} \mathbf{C}\right)\end{array}$ \\
\hline J & 0.40 & 3.33 & 1.88 & 2.19 & 235.90 & 13.58 & 24.00 \\
F & - & - & - & - & - & - & - \\
M & 0.50 & 2.35 & 3.20 & 3.04 & 204.80 & 11.95 & 19.00 \\
A & 3.06 & 2.42 & 2.36 & 2.89 & 93.20 & 11.12 & 21.00 \\
M & 4.18 & 2.96 & 1.66 & 1.91 & 85.50 & 10.48 & 18.00 \\
J & 4.33 & 3.59 & 1.70 & 2.80 & 67.80 & 10.23 & 15.00 \\
J & 3.13 & 5.92 & 2.57 & 2.13 & 128.70 & 10.27 & 17.00 \\
A & 5.34 & 7.02 & 1.72 & 3.14 & 183.50 & 10.55 & 17.00 \\
S & 3.27 & 7.91 & 3.77 & 3.14 & 160.90 & 11.58 & 18.50 \\
0 & 2.00 & 2.20 & 3.14 & 2.30 & 92.60 & 12.18 & 22.00 \\
N & 3.45 & 1.56 & 2.80 & 2.51 & 72.80 & 13.37 & 22.00 \\
D & 2.34 & 5.23 & 1.90 & 2.33 & 126.50 & 13.87 & 23.00 \\
J & 2.54 & 7.64 & 1.72 & 1.62 & 70.40 & 13.97 & 23.40 \\
F & 2.30 & 6.01 & 2.30 & 2.16 & 83.30 & 13.62 & 24.00 \\
\hline
\end{tabular}



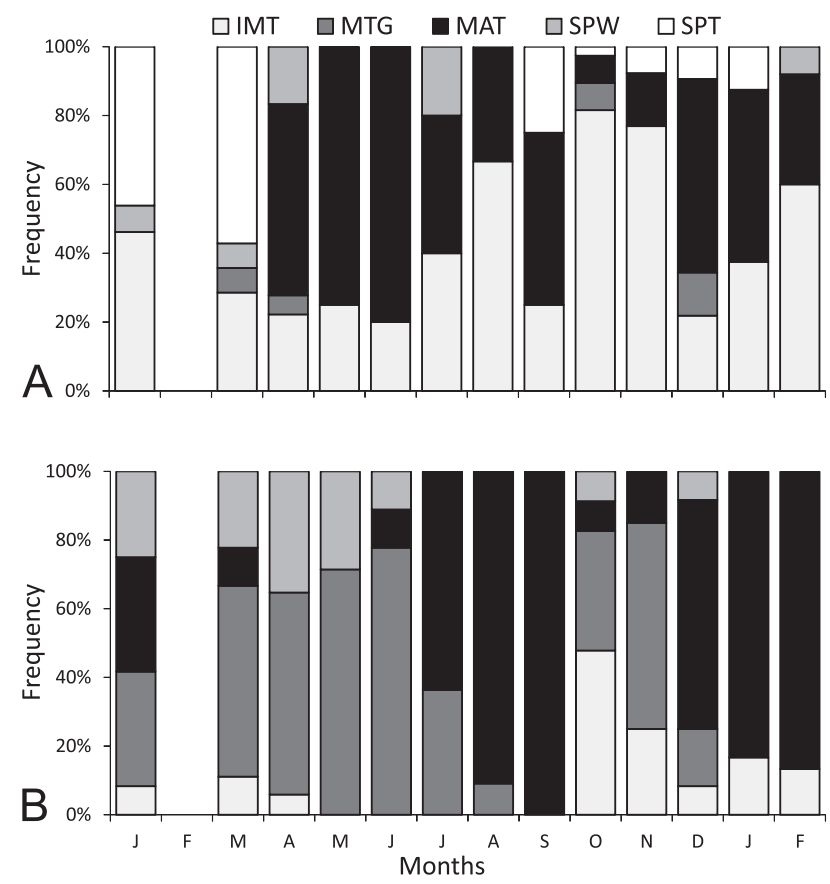

Figure 1. Frequency of occurrence of gonadal maturation stages for males (A) and females (B) of Mimagoniates microlepis from site 1 in Maquiné, RS, Brazil, between January 1998 and February 1999. IMT = immature; MTG = maturing; $M A T=$ mature; $S P W=$ spawning; $S P T=$ spent.
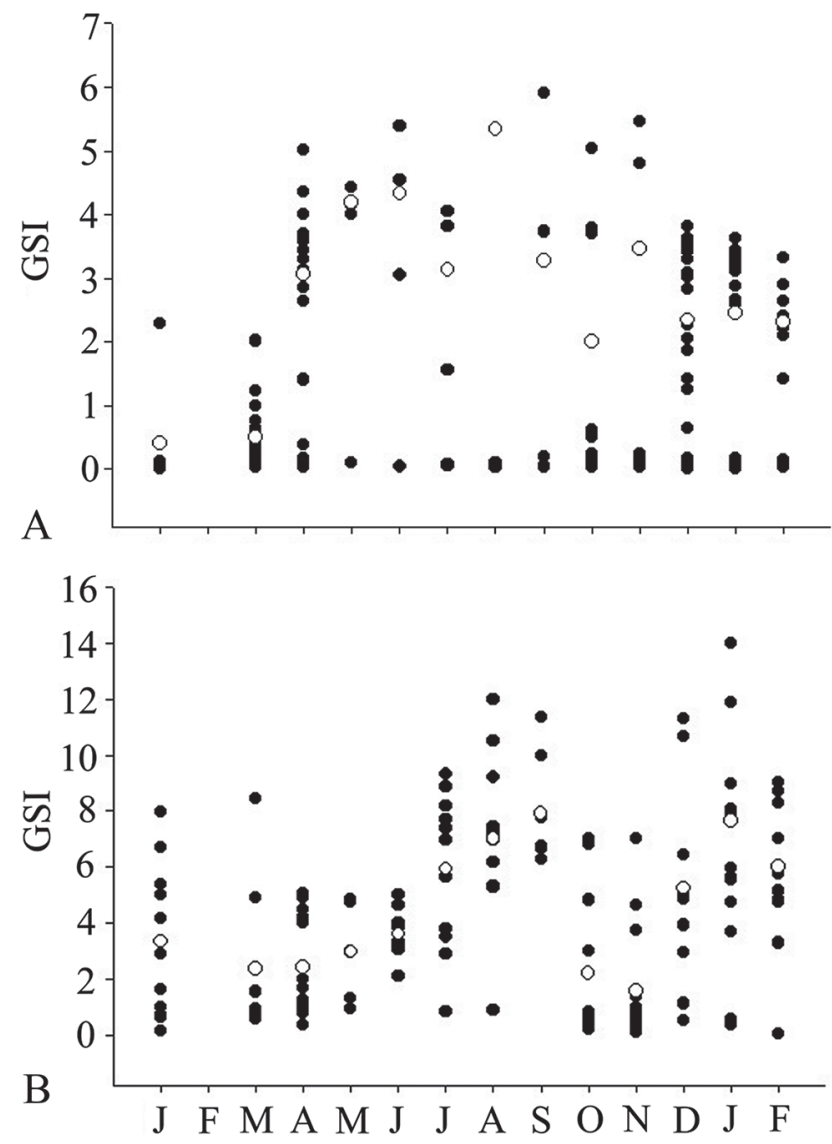

\section{MONTHS}

Figure 2. Monthly values of the gonadosomatic index (GSI) to males (A) and females (B) of Mimagoniates microlepis from site 1 in Maquiné, RS, Brazil, between January 1998 and February 1999. Open circles = average value. turbid water due to the muddy bottom. Temperature ranged from $15^{\circ} \mathrm{C}$ to $24^{\circ} \mathrm{C}$, and the average was $20.3^{\circ} \mathrm{C}$ ( \pm 3.04 SD) (Table 1).

The frequency of gonadal maturation stages indicates that both males and females have mature individuals in most months (Figs. 1A-B) suggesting a non-seasonal reproductive period. The GSI average values of males ranged from 0.4 to 5.34 with highest values in May (4.18), June (4.33), and August (5.34); other high values were observed in September (3.27) and November (3.45). Females GSI averages ranged from 1.56 to 7.91 , with highest values in August (7.02), September (7.91) and January (7.64), and other high values in July (5.92), December (5.23) and February (6.01) (Figs. 2A-B). Therefore, mature specimens of both sexes may occur in most months. The highest reproductive activity of males seems to be in winter and spring in the southern hemisphere, between April and September and in November. In females, highest reproductive activity occurs in winter, spring and summer, between July and September and between December and February 1999.

The nonparametric Spearman rank indicated a negative and significant correlation between the average values of male's GSI and water temperature ( $r=-0.7366$; $p=0.0041$ ). No correlation was found between female's GSI and water temperature, and the other parameters (RSW, rainfall and day length) did not show correlation with males and females GSI.

Fecundity data was obtained from the analysis of 15 mature $M$. microlepis females which ranged from 26.65 to $32.44 \mathrm{~mm} \mathrm{SL}$ and indicate a minimal of 50 and maximum of 274 yolky oocytes with average of 135.7 ( \pm 73.4 SD). Relative fecundity ranged from 0.17 to 0.47 oocytes per milligram with an average of 0.27 ( $\pm 0.10 \mathrm{SD}$ ). The biggest oocyte measured $1.14 \mathrm{~mm}$, and the average size of the yolky oocytes was $0.87 \mathrm{~mm}$ ( $\pm 0.17 \mathrm{SD}$ ). Based on the analysis of the same females, the species showed an oocyte development of the type synchronic in two groups. This kind of oocyte development is defined by the presence of a large number of translucent oocytes with a small diameter and a peak of large, yolky oocytes ready to be released (Fig. 3). Dispersion between the average

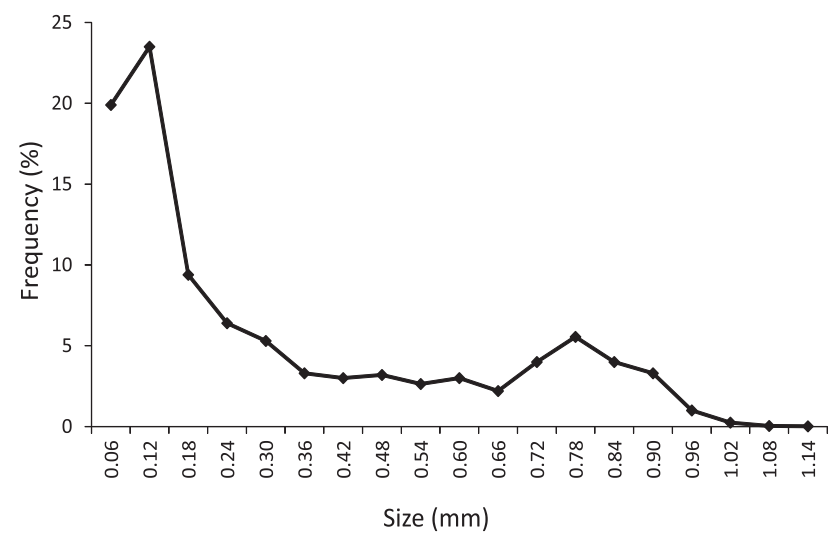

Figure 3. Distribution of the relative frequencies of oocyte diameter in the mature ovaries in females of Mimagoniates microlepis from site 1 in Maquiné, RS, Brazil, between January 1998 and February 1999. 
Table 2. Monthly variation in mean values of GSI, RSW for males and females of Mimagoniates rheocharis from site 1 in Maquiné, RS, Brazil, and water temperature data (January 1998 to February 1999). GSI = gonadosomatic index; $\mathrm{RSW}=$ relative stomach weight.

\begin{tabular}{cccccc}
\hline Month & GSI $\sigma^{7}$ & GSI 9 & RSW $\sigma^{7}$ & RSW 9 & Temperature $\left({ }^{\circ} \mathbf{C}\right)$ \\
\hline J & 1.22 & 0.68 & 1.91 & 2.36 & 24.00 \\
F & - & - & - & - & - \\
M & 0.86 & 0.96 & 2.38 & 2.56 & 19.00 \\
A & 1.01 & 1.30 & 3.43 & 2.68 & 20.00 \\
M & 4.10 & 2.77 & 1.75 & 2.46 & 18.00 \\
J & 3.26 & 2.00 & 2.44 & 2.97 & 15.50 \\
J & - & - & - & - & 17.00 \\
A & 2.33 & - & 1.83 & - & 17.00 \\
S & - & 1.44 & - & 2.54 & 18.50 \\
O & 0.98 & 0.32 & 4.90 & 2.67 & 21.00 \\
N & - & - & - & - & 22.00 \\
D & 2.71 & 5.97 & 1.33 & 1.31 & 22.50 \\
J & 1.84 & 2.86 & 1.42 & 2.21 & 23.70 \\
F & 0.17 & 1.72 & 2.10 & 2.20 & 25.00 \\
\hline
\end{tabular}

values of absolute fecundity and standard length and fecundity and total weight were adjusted to a power equation $\left(y=20.775 x^{0.0773} ; R^{2}=0.5778\right.$ and $y=0.0743 x^{0.3826}$; $R^{2}=0.8224$; respectively). Dispersion between fecundity and gonad weight were adjusted to a linear equation ( $y=0.0002 x+0.0189 ; R^{2}=0.8812$ ).

The samples of $M$. rheocharis from site 1 have 84 males ranging from 20.11 to $43.02 \mathrm{~mm} \mathrm{SL}$ and 63 females ranging from 19.17 to $35.45 \mathrm{~mm}$ SL. In July, September and November 1998 there were no males in the samples as well as no females were collected in July and August.
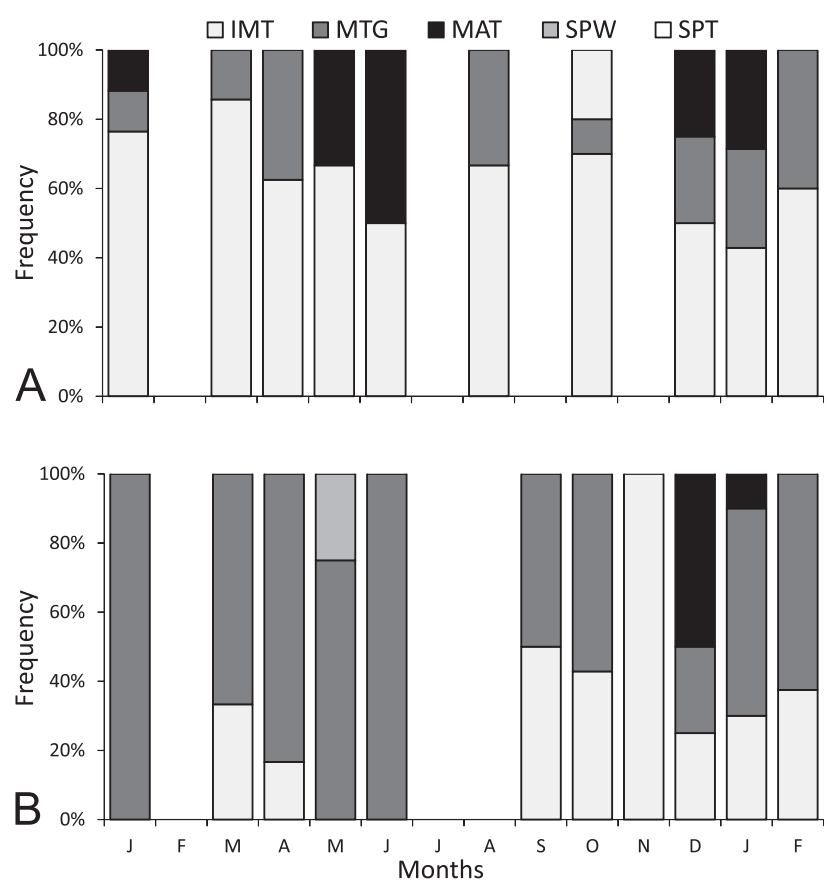

Figure 4. Frequency of occurrence of gonadal maturation stages for males (A) and females (B) of Mimagoniates rheocharis from site 1 in Maquiné, RS, Brazil, between January 1998 and February 1999. IMT = immature; MTG = maturing; $M A T=$ mature; $S P W=$ spawning; $S P T=$ spent.
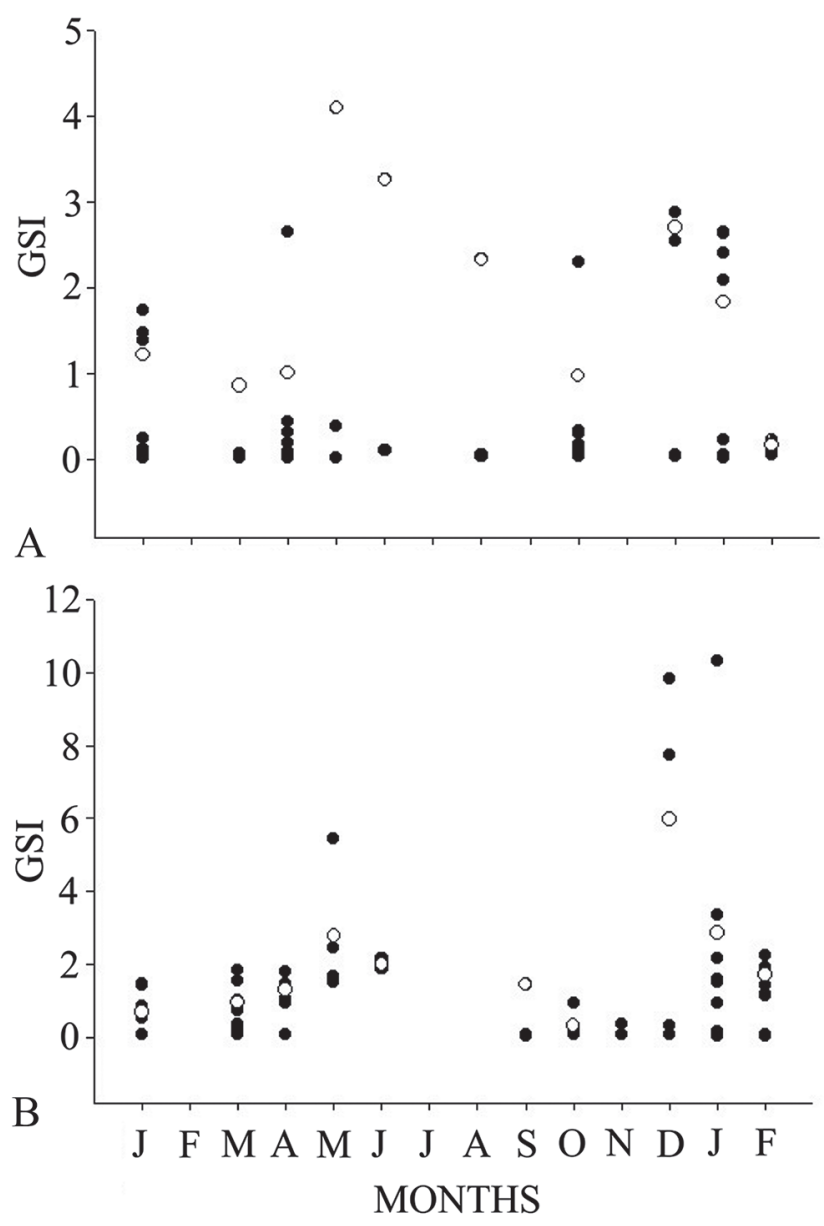

Figure 5. Monthly values of the gonadosomatic index (GSI) for males (A) and females (B) of Mimagoniates rheocharis from site 1 in Maquiné, RS, Brazil, between January 1998 and February 1999. Open circles = average value.

In some months, the samples consisted of two to five individuals only. The fish were sampled in small rapids with shallow and crystalline water, often occurring in small pools formed by the protection provided by stones and vegetation. Temperature ranged from $15.5^{\circ} \mathrm{C}$ to $25^{\circ} \mathrm{C}$ with an average of 20.25 ( \pm 3.04 SD) (Table 2).

Despite the low number of specimens in the samples, the analysis of the frequencies of gonadal maturation stages indicates two periods of high reproductive activity for males (May and June 1998 and December 1998 and January 1999), with mature specimens also in January 1998. Females showed a peak of reproductive activity in December 1998 and January 1999, with spawning females occurring in May (Figs. 4A-B). The GSI average of males ranged from 0.17 to 4.1 with high values in May (4.1), June (3.26) and December (2.71). In females, GSI averages ranged from 0.32 to 5.97 with highest values occurring in May (2.77), December (5.97) and January (2.86) (Figs. 5A-B).

Due to the low number of specimens in the samples and no mature females, fecundity and spawning type were not analyzed for $M$. rheocharis from this site. Spearman correlation rank did not reveal any correlation between GSI and RSW, rainfall, day length, and temperature. 
Table 3. Monthly variation in mean values of GSI, RSW for males and females of Mimagoniates rheocharis from site 2 in Maquiné, RS, Brazil, and rainfall, day length and water temperature data (January 1998 to February 1999). $\mathrm{GSI}=$ gonadosomatic index; RSW = relative stomach weight.

\begin{tabular}{|c|c|c|c|c|c|c|c|}
\hline Month & GSI o' & GSI + & RSW ơ & RSW 9 & $\begin{array}{c}\text { Rainfall } \\
\text { (mm) }\end{array}$ & $\begin{array}{c}\text { Day } \\
\text { length } \\
\text { (hours) }\end{array}$ & $\begin{array}{c}\text { Temperature } \\
\left({ }^{\circ} \mathrm{C}\right)\end{array}$ \\
\hline $\mathrm{J}$ & 0.06 & 0.80 & 4.60 & 4.40 & 235.90 & 13.58 & 26.00 \\
\hline $\mathrm{F}$ & - & - & - & - & - & - & - \\
\hline M & 0.35 & 0.74 & 3.63 & 2.81 & 204.80 & 11.95 & 20.00 \\
\hline A & 0.60 & 3.50 & 3.75 & 2.78 & 93.20 & 11.12 & 20.00 \\
\hline M & 3.18 & 1.67 & 1.64 & 3.52 & 85.50 & 10.48 & 18.00 \\
\hline J & 0.06 & 6.90 & 2.12 & 2.73 & 67.80 & 10.23 & 16.00 \\
\hline $\mathrm{J}$ & 2.60 & 0.09 & 1.12 & 2.26 & 128.70 & 10.27 & 17.00 \\
\hline A & 2.18 & 8.17 & 2.40 & 1.70 & 183.50 & 10.55 & 17.00 \\
\hline$S$ & 0.23 & 10.25 & 2.30 & 2.21 & 160.90 & 11.58 & 31.00 \\
\hline 0 & - & - & - & - & 92.60 & 12.18 & 20.00 \\
\hline $\mathrm{N}$ & 0.06 & - & 3.02 & - & 72.80 & 13.37 & 22.00 \\
\hline D & 0.08 & 1.07 & 2.32 & 3.05 & 126.50 & 13.87 & 23.00 \\
\hline $\mathrm{J}$ & - & - & - & - & 70.40 & 13.97 & 23.70 \\
\hline $\mathrm{F}$ & - & 0.75 & - & 1.20 & 83.30 & 13.62 & 24.00 \\
\hline
\end{tabular}

Site 2 - The samples were represented by very few individuals on this site, mainly for M. microlepis and no analysis was performed for this species. The water temperature ranged from $17^{\circ} \mathrm{C}$ to $26^{\circ} \mathrm{C}$ with an average of $21.36^{\circ} \mathrm{C}$ ( \pm 4.22 SD) (Table 3).

The samples were represented by 40 males of $M$. rheocharis whose SL ranged from 20.10 to $42.50 \mathrm{~mm}$, and 42 females ranging from 17.50 to $35.84 \mathrm{~mm}$. No males were captured in October, January and February 1999. Only
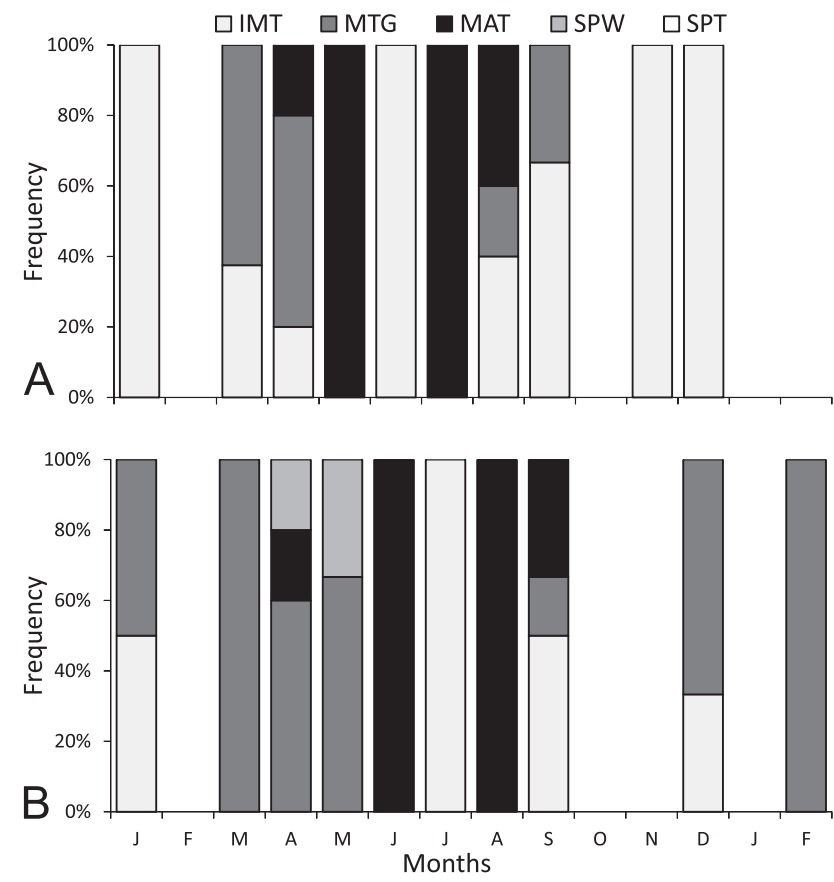

Figure 6. Frequency of occurrence of gonadal maturation stages for males (A) and females (B) of Mimagoniates rheocharis from site 2 in Maquiné, RS, Brazil, between January 1998 and February 1999. IMT = immature; MTG = maturing; $M A T=$ mature; $S P W=$ spawning.
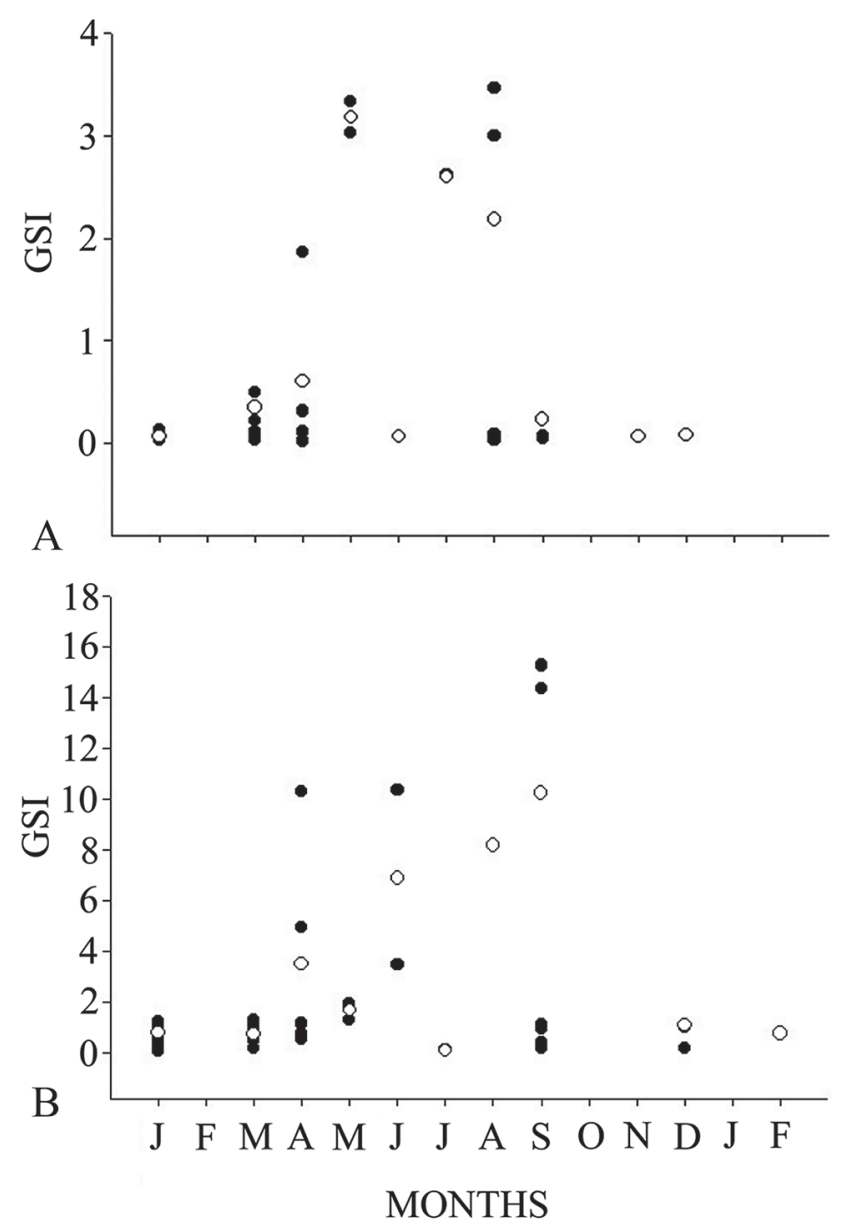

Figure 7. Monthly values of the gonadosomatic index (GSI) to males (A) and females (B) of Mimagoniates rheocharis from site 2 in Maquiné, RS, Brazil, between January 1998 and February 1999. Open circles = average value.

immature males occurred in January, June, November and December 1998. No females were captured in October, November and January 1999; only an immature female was sampled in July (Figs. 6A-B). The GSI average values for males ranged from 0.23 in September to 3.18 in May, with high values in July (2.6) and August (2.18). Females GSI averages varied from 0.74 in March to 10.25 in September, with high values in June (6.9) and August (8.17) (Figs. 7A-B).

No correlation was found between GSI average values of both males and females $M$. rheocharis with the tested parameters (RSW, rainfall, day length and water temperature).

Fecundity was obtained through the analysis of five M. rheocharis mature females (ranging from 28.73 and $35.84 \mathrm{~mm} \mathrm{SL}$ ), and the number of yolky oocytes ranged from 98 to 438 with an average of 273.4 ( \pm 127.86 SD). Relative fecundity ranged from 0.17 to 0.46 oocytes per milligram with an average of 0.33 ( $\pm 0.11 \mathrm{SD}$ ). The biggest oocyte recorded was $1.02 \mathrm{~mm}$, and the average size of yolky oocytes was $0.81 \mathrm{~mm}$ ( $\pm 0.14 \mathrm{SD})$. The type of oocyte development of $M$. rheocharis follows what was found for M. microlepis; the species can be considered a total spawner, showing many small oocytes and a peak of bigger oocytes ready to be released (Fig. 8). Dispersion 


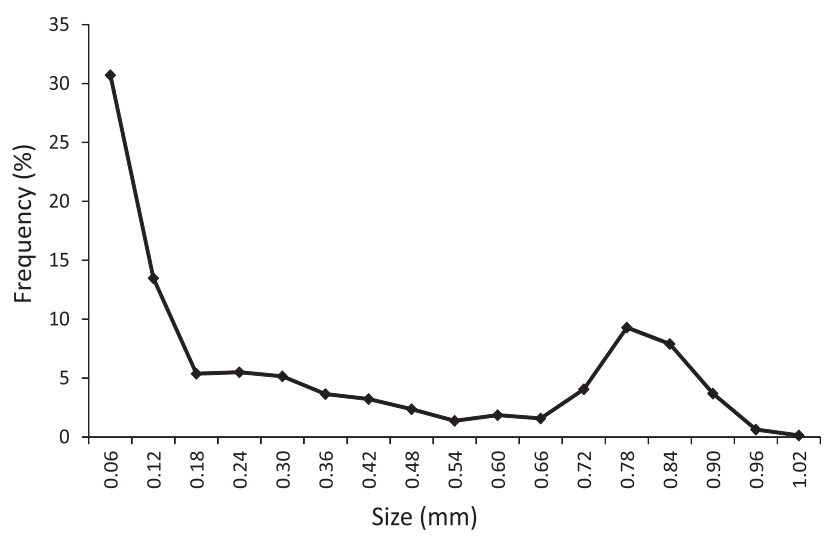

Figure 8. Distribution of the relative frequencies of oocyte diameter in mature ovaries in Mimagoniates rheocharis from site 2 in Maquiné, RS, Brazil, between January 1998 and February 1999.

between absolute fecundity and $\mathrm{SL}$, and between fecundity and total weight showed an exponential relationship ( $y=26.855 \mathrm{e}^{0.0007 \mathrm{x}} ; \mathrm{R}^{2}=0.9$ e $\mathrm{y}=0.4743 \mathrm{e}^{0.0018 \mathrm{x}}$; $\mathrm{R}^{2}=0.7397$; respectively). Dispersion between fecundity and gonads weight revealed a linear relationship $\left(y=0.0003 x+0.0187 ; R^{2}=0.9688\right)$.

\section{DISCUSSION}

The results indicate a non-seasonal reproductive period for both $M$. microlepis and $M$. rheocharis in this study. Mature individuals occurred in most months suggesting the absence of a marked seasonality. No correlation with biotic and abiotic factors was observed, except for a negative and significant correlation between the GSI of males of $M$. microlepis and water temperature. The same was found concerning females GSI and water temperature in Azevedo et al. (2016).

Results also indicated that absolute and relative fecundity are quite low when compared to other characids (Azevedo, 2010), suggesting that the small number of mature oocytes are spawned at once within each reproductive event (total spawning). The mean values of absolute and relative fecundities observed in this study are close to those found by Azevedo et al. (2016) for the same species. According to this author, the absolute fecundity of M. microlepis ranged from 38 to 288 oocytes with an average of 109.33 , and relative fecundity of 0.27 while $M$. rheocharis showed 128 to 808 oocytes with an average of 421.05 and relative fecundity of 0.36 . The low fecundity found for the species of the Glandulocaudini was attributed to the existence of insemination, which would guarantee fecundation of most oocytes even in spite of their low production (Azevedo et al., 2000). The low fecundity observed in inseminating and non-inseminating characids (Silvano et al., 2003; Oliveira, 2003; Lampert et al., 2004; Gonçalves et al., 2005) however, suggests that low oocyte production might be a characteristic that appeared in some characid groups independently of the presence of insemination. Body size reduction may represent an evolutionary innovation shared by monophyletic groups within the Characidae, and low fecundity would be a consequence of this reduction (Azevedo, 2010).

Many studies about reproduction within characid species indicate that temperature and day length influence the reproductive process which is usually seasonal during spring and summer, and short (three to six months) (Vazzoler \& Menezes, 1992; Azevedo, 2004, 2010). On the other hand of what is described for most South American characids, a small number of species reproduce during different months or show a non-seasonal reproductive period (Azevedo, 2010). This is especially true for the Mimagoniates species herein studied and also from Azevedo et al. (2016), which show a reproductive period that includes the coldest months even though mature males and GSI peaks may also occur in the summer.

According to Azevedo (2010), reproductive traits such as seasonality in the reproductive period, high fecundity, and external fertilization seem to represent an ancestral reproductive pattern found in most Characiformes and in species belonging to the more basal groups of the Characidae, which usually reach larger sizes.

Body size reduction observed in putatively more derived lineages of the Characidae may represent a synapomorphy and may have led to the selection of other adaptations, such as some modifications in the reproductive pattern of the Characiformes (Azevedo, 2010).

The reduction of oocyte storage capacity might be one of the major consequences of body size reduction, which, for some species may be compensated by multiple spawning (Azevedo, 2010). On the other hand, species which have maintained total spawning would need to develop other mechanisms to counterbalance this limitation. Therefore, the enhancement of the reproductive period and insemination itself may represent the evolutionary responses to the reduction in body size and fecundity.

According to Bagenal (1967), fish's length seems to be a better indicator of their oocyte production capacity more than weight because fish size does not significantly decrease while weight might vary along the year. However, gonad weight is a straight indicator of this capacity because it shows a linear relationship with fecundity, indicating that both increase proportionally.

The Mimagoniates species herein studied show oocyte development of the type synchronic in two groups, where two oocyte batches can be distinguished: small and numerous oocytes from the reserve stock and bigger oocytes which should mature synchronically and be released during the reproductive period (Wallace \& Sellman, 1981). This spawning type is typical of species that spawn periodically along its lifetime (Vazzoler, 1996). However, as apparently there are no seasonal restrictions on the reproduction of Mimagoniates species, it is possible that a single female might be able to spawn more than once in a short period. This type of oocyte development indicates total spawning, where one oocyte batch is released in each reproductive event. Multiple spawning allows a larger production of oocytes within 
a reproductive season than would be predictable, considering fish size. This strategy is observed in many small sized characids (Winemiller, 1989; Vazzoler \& Menezes, 1992; Vazzoler, 1996; Gelain et al., 1999; Oliveira et al., 2002; Oliveira, 2003; Lampert et al., 2004). However, total spawning is also recorded for small sized inseminated species, occurring in the diapomin Diapoma terofali and the compsurin Macropsobrycon uruguayanae (Azevedo, 2004).

The yolky oocytes observed in $M$. microlepis and M. rheocharis have diameters similar to those described for other stevardiine species such as Diapoma terofali (1.22 mm; Azevedo, 2004) and Macropsobrycon uruguayanae (1.014 mm; Azevedo, 2004), but bigger than those described for Gephyrocharax atrocaudata (0.7-0.8 mm; Kramer, 1978) and Pseudocorynopoma doriae (0.7742 mm; Ferriz et al., 2007). Few studies provide data concerning oocyte size. This information, allied to fecundity and spawning type data, would help the discussion about reproductive strategies of fishes. In Azevedo's (2004) revision, the mature oocyte diameter in Characidae species ranges from 0.7 to $1.9 \mathrm{~mm}$. According to this author, reduction in mature oocyte size to improve fecundity or the enlargement of oocyte size to improve chances of survival of the fry may represent adaptations to fecundity and body size reduction in the Characidae.

Braga et al. (2006) found that the reproductive period of $M$. microlepis from the Colônia Pereira river in Paraná, occurs during the spring and summer, synchronized with rainfall. In another stream in Paraná, Braga et al. (2008) found a reproductive period restricted to winter and spring also for $M$. microlepis. The results presented here corroborate the hypothesis that inseminating species such as Mimagoniates show some traits that differ from the reproductive pattern observed in most Characiformes, reinforcing the idea that such features represent evolutionary adaptations within this group.

\section{CONCLUSIONS}

Both species herein studied present a non-seasonal pattern of reproduction without a clear relationship with the variation of biotic and abiotic factors. High GSI peaks were also observed including the coldest months even though mature males and GSI peaks may also occur in the summer. Both species also produce a low number of oocytes when compared to other fish within the same family; on the other hand, low fecundity is also shared with other inseminating characids. This might be related to the reduction in the oocyte storage capacity as a consequence of body size reduction. Both species were characterized as total spawners, i.e., developing and spawning one mature oocyte batch during each reproductive cycle. However, considering a non-seasonal reproduction, it is likely that females complete more than one cycle of gonadal maturation within a year. A non-seasonal reproduction, low fecundity, total spawning, and insemination may represent evolutionary responses to the reduction in body size and fecundity. These features may indicate adaptive advantages which may enhance the chance of survival even with low energetic investment and improved fertilization.

\section{ACKNOWLEDGEMENTS}

To Luiz Malabarba and Clarice Fialho for providing logistic and technical support in the Laboratório de Ictiologia/UFRGS.

\section{REFERENCES}

Adebisi, A.A. 1987. The relationships between fecundities, gonadosomatic indices and egg sizes of some fishes of Ogun River, Nigeria. Archiv für Hydrobiologie, 111: 151-156.

Atkins, D.L. \& Fink, W.L. 1979. Morphology and histochemistry of the caudal gland of Corynopoma riisei Gill. Journal of Fish Biology, 14: 465-469.

Azevedo, M.A. 2004. Análise comparada de caracteres reprodutivos em três linhagens de Characidae (Teleostei: Ostariophysi) com inseminação. (Doctoral Thesis). Universidade Federal do Rio Grande do Sul, Porto Alegre, Brasil. 239p.

Azevedo, M.A. 2010. Reproductive characteristics of characid fish species (Teleostei, Characiformes) and their relationship with body size and phylogeny. Iheringia, Série Zoologia, Porto Alegre, 100(4): 469-482.

Azevedo, M.A.; Fialho, C.B.\& Malabarba, L.R. 2016. Reproductive strategies in two inseminating species of Glandulocaudini, Mimagoniates microlepis and Mimagoniates rheocharis (Characiformes: Characidae: Stevardiinae). Journal of Fish Biology, 89(1): 431-444. D0I

Azevedo, M.A.; Malabarba, L.R. \& Fialho, C.B. 2000. Reproductive biology of the inseminated Glandulocaudinae Diapoma speculiferum Cope (Acinopterygii: Characidae). Copeia, (4): 983-989.

Bagenal, T.B. 1967. A short review of fish fecundity. In: Gerking, S.D. (Ed.). The biological basis of freshwater fish production. Oxford, Blackwell. p. 89-111.

Braga, M.R.; Aranha, J.M.R. \& Vitule, J.R. 2008. Reproduction period of Mimagoniates microlepis, from an Atlantic Forest Stream in southern Brazil. Brazilian Archives of Biology and Technology, 51(2): 345-351.

Braga, M.R.; Menezes, M.S. \& Aranha, J.M.R. 2006. Táticas reprodutivas de Mimagoniates microlepis (Steindachner, 1876) (Characidae, Glandulocaudinae) no rio Colônia Pereira, Paranaguá, Paraná. Estudos em Biologia, 28(65): 13-20.

Burns, J.R. \& Weitzman, S.H. 2005. Insemination in ostariophysan fishes. In: Grier, H. \& Uribe, M.C. (Eds.). Viviparous Fishes. Mexico, New Life Publications. p. 107-134.

Burns, J.R.; Weitzman, S.H.; Grier, H.J. \& Menezes, N.A. 1995. Internal fertilization, testis and sperm morphology in glandulocaudine fishes (Teleostei: Characidae: Glandulocaudinae). Journal of Morphology, 210: 45-53.

Castro, R.M.C.; Ribeiro, A.C.; Benine, R.C. \& Melo, A.L.A. 2003. Lophiobrycon weitzmani, a new genus and species of glandulocaudine fish (Characiformes: Characidae) from the rio Grande drainage, upper rio Paraná system, southeastern Brazil. Neotropical Ichthyology, 1(1): 11-19.

Ferriz, R.A.; Fernandez, E.M.; Bentos, C.A. \& Lopez, G.R. 2007. Reproductive biology of Pseudocorynopoma doriae (Pisces: Characidae) in the High Basin of the Samborombón River, province of Buenos Aires, Argentina. Journal of Applied Ichthyology, 23(3): 226-230.

Gelain, D.; Fialho, C.B. \& Malabarba, L.R. 1999. Biologia reprodutiva de Serrapinnus calliurus (Characidae, Cheirodontinae) do arroio Ribeiro, 
Barra do Ribeiro, Rio Grande do Sul, Brasil. Comunicações do Museu de Ciência e Tecnologia, PUCRS, Série Zoologia, 12: 71-82.

Gonçalves, T.K.; Azevedo, M.A.; Malabarba, L.R. \& Fialho, C.B. 2005. Reproductive biology and development of sexually dimorphic structures in Aphyocharax anisitsi (Ostariophysi: Characidae). Neotropical Ichthyology, 3(3): 433-438.

Kramer, D.L. 1978. Reproductive seasonality in fishes of a tropical stream. Ecology, 59(5): 976-985.

Lampert, V.R.; Azevedo, M.A. \& Fialho, C.B. 2004. Reproductive biology of Bryconamericus iheringii (Ostariophysi: Characidae) from rio Vacacaí, RS, Brazil. Neotropical Ichthyology, 2(4): 209-215.

Mazzoni, R. \& Iglesias-Rios, R. 2002. Environmentally related life history variations in Geophagus brasiliensis. Journal of Fish Biology, 61: 1606-1618.

Menezes, N.A. \& Weitzman, S.H. 2009. Systematics of the Neotropical fish subfamily Glandulocaudinae (Teleostei: Characiformes: Characidae). Neotropical Ichthyology, 7(3): 295-370.

Myers, N.; Mittermeier, R.A.; Mittermeier, C.G.; Fonseca, G.A.B. \& Kent, J. 2000. Biodiversity hotspots for conservation priorities. Nature, 403: 853-858.

Nelson, K. 1964. Behavior and morphology in the glandulocaudine fishes (Ostariophysi, Characidae). University of California Publications in Zoology, 75(2): 59-152.

Oliveira, C.L.C.; Fialho, C.B. \& Malabarba, L.R. 2002. Período reprodutivo, desova e fecundidade de Cheirodon ibicuhiensis Eigenmann, 1915 (Ostariophysi: Characidae) do arroio Ribeiro, Rio Grande do Sul, Brasil. Comunicações do Museu de Ciência e Tecnologia, PUCRS, Série Zoologia, 15(1): 3-14
Oliveira, C.L.C. 2003. Análise comparada de caracteres reprodutivos e da glândula branquial de duas espécies de Cheirodontinae (Teleostei: Characidae). (Dissertação de Mestrado). Universidade Federal do Rio Grande do Sul, Porto Alegre, Brasil. 80p.

Reis, R.E.; Kullander, S.0. \& Ferraris Jr., C.J. (Eds.). 2003. Check list of freshwater fishes of South and Central America. Porto Alegre, EDIPUCRS. 742p.

Santos, E.P. dos. 1978. Dinâmica de populações aplicada à pesca e piscicultura. São Paulo, HUCITEC, Editora da Universidade de São Paulo. 129p.

Silvano, J.; Oliveira, C.L.C.; Fialho, C.B. \& Gurgel, H.C.B. 2003. Reproductive period and fecundity of Serrapinnus piaba (Characidae: Cheirodontinae) from the rio Ceará Mirim, Rio Grande do Norte, Brazil. Neotropical Ichthyology, 1(1): 61-66.

Vazzoler, A.E.A.M. 1996. Biologia da reprodução de peixes teleósteos: teoria e prática. Maringá, EDUEM. 169p.

Vazzoler, A.E.A.M. \& Menezes, N.A. 1992. Síntese dos conhecimentos sobre o comportamento reprodutivo dos Characiformes da América do Sul (Teleostei, Ostariophysi). Revista Brasileira de Biologia, 52(4): 627-640.

Wallace, R.A. \& Sellman, K. 1981. Cellular and dynamic aspects of oocyte growth in teleosts. American Zoologist, 21(2): 325-343.

Weitzman, S.H. \& Fink, S.V. 1985. Xenurobryconin phylogeny and putative pheromone pumps in glandulocaudine fishes (Teleostei, Characidae). Smithsonian Contributions to Zoology, 421: 1-121.

Weitzman, S.H.; Menezes, N.A. \& Burns, J.R. 1996. Species of the glandulocaudine tetra tribe Glandulocaudini: comments from ongoing research. Tropical Fish Hobbyist, 4: 100-108.

Winemiller, K.0. 1989. Patterns of variation in life history among South American fishes in seasonal environments. Oecologia, 81: 225-241. 